\title{
A NEW ISOLATE OF SCLEROTIUM ROLFSII SACC. CAUSING BULB ROT IN ONION (ALLIUM CEPA L. VARIETY POONA RED)
}

\author{
NIRAN JANI RAMANATHAN* , B . SIVAKADACHAM AND \\ K . THEIVENDIRARAJAH \\ Department of Botany, University of Jaffna, Jaffna, Sri Lanka.
}

(Date of receipt : 03 March 1987)

(Date of acceptance : 25 February 1988)

\begin{abstract}
The causative fungus of a hitherto unreported bulb rot aisease of onion (Allium cepa L. variety Poona red) was found to be Sclerotium rolfsii Sacc. The vegetative propagative structures of the fungus known as sclerotia, were able to germinate within $24 \mathrm{~h}$ on a suitable substratum and produce new colonies. The fungus took about ten days to produce fresh sclerotia from germinating sclerotia, under laboratory conditions. The fungal isolate obtained from infected onion plants (Sclerotium rolfsii - Isolate 5) had a temperature optimum of $35^{\circ} \mathrm{C}$ for germination of sclerotia. It showed luxurious growth and maximum amount of sclerotial production at temperatures between 30 and $35^{\circ} \mathrm{C}$. The fungus was able to survive in a wide range of $\mathrm{pH}$ conditions ( $\mathrm{pH} 3$ to 9) but had an optimum pH of 5.5 for germination of sclerotia and radial growth.
\end{abstract}

\section{Introduction}

Sclerotium rolfsii Sacc. is a versatile soil borne pathogen attacking several crop plants. 7 It is widespread throughout the moist tropics and warmer region of the temperate zone and has an extensive and varied host range. ${ }^{2}$ It has been found to cause a variety of diseases namely damping off of seedlings, collar or stem rot, ${ }^{1}$ foot rot, crown rot, Sclerotium wilt and blight. ${ }^{3}$ The sequence of events during the maceration or death and decay of host tissue resulting in the formation of symptoms has been found to be complicated as suggested by Punja et al. ${ }^{5}$

The fungus forms sclerotia during unfavourable conditions and remains in the soil for long periods without being affected by adverse soil and environmental conditions. When favourable conditions intervene and if suitable substrata are available, the sclerotia germinate producing clusters of hyphae around them. ${ }^{4}$

In July, 1986 our attention was drawn to a disease of Bombay onion (Allium cepa. $L_{\text {.) }}$ ) in the Arali area of Jaffna. The onion plants of the variety Poona red were attacked by a fungus. The disease occurred in the seed bed when the plants were about 45 days old. Symptoms were associated with bulb rot. However, the initial symptoms appeared as yellowing of tips of onion scales or leaves. The discolouration was found to spread down the leaves and the tips became necrotic and brown. The above symptoms were

* Division of Plant Patbology, Central Agricultural Researcb Institute, Gannoruwa, Peradeniya, Sri Lanka. 
followed by wilting of scathes. Groups or patches of plants showing the above symptoms appeared in the field. On close examination of uprooted diseased plants, the bulbs were found to have withered with the complete loss of their root system. Strands of white fan shaped hyphae were seen on the bulbs. These clusters of hyphae also enveloped the base of the stem near soil level. The rotten plant material and the soil samples taken from around these plants when examined showed presence of numerous, tiny, white or yellow-brown sclerotia at various: developmental stages and in the form of strands. Each of the hyphal strands found on the surface of bulbs consisted of 4-10 hyphae. From the characteristic growth of hyphae and the size and shape of sclerotia, the fungus was identified as Sclerotium rolfsii Sacc. The identity of the fungus was confirmed by Commonwealth Mycological Institute (CMI Report No: H107/86/YS18).

The fungus was constantly associated with the symptoms produced on onion bulbs in the field. This is in fact the first record of the disease caused by $S$. rolfsii on onion variety-Poona red in Sri Lanka. The fungus obtained from affected bulbs was referred to as Sclerotium rolfsii - Isolate 5 .

\section{Experimental}

Infected onion bulbs (variety Poona red) were collected from the field and brought to the laboratory. These were washed with tap water, surface sterilized by dipping in $0.5 \%$ sodium hypochlorite solution for $1 \mathrm{~min}$ and then washed in 3-4 changes of sterile distilled water. Small pieces from surface sterilized bulbs were transferred on to freshly poured Potato Dextrose Agar (PDA) plates and incubated at room temperature $\left(30+4^{\circ} \mathrm{C}\right)$ for seven days.

The morphology of the colony and of the fungus on PDA was noted. Measurements of length and breadth of primary; secondary and tertiary hyphae were made under a light microscope from a 3 day old colony of the fungus. Hand sections of mature sclerotia were also made and examined under the microscope.

Following observations on the morphology of the fungus, studies were made on germination of sclerotia, radial growth of mycelium and sclerotial production after different periods of incubation on PDA. For studies on germination of sclerotia mature brown sclerotia were dislodged from the surface of a ten day old colony with a soft brush and transferred on to fresh PDA plates. Ten sclerotia were transferred on to each of 5 PDA plates and incubated at room temperature under continuous illumination ( $7 \mathrm{kl}$ ). The percentage sclerotial germination was determined at $24 \mathrm{~h}$ intervals during incubation. The diameter of colonies formed from the germinating sclerotia were also measured at $24 \mathrm{~h}$ intervals along two predetermined diameters at right angles to each other. Radial growth of the fungus was also studied by inoculating 10 fresh PDA plates at the centre with $0.8 \mathrm{~cm}$ diameter mycelial discs cut from the advancing region of a 6 day old colony of Sclerotium 
rolfsii - Isolate 5 . These plates were also incubated as before for 7 days and the diameter of colonies was measured daily. Sporulation was measured by counting the number of sclerotia produced per plate and then converting the value to number of sclerotia produced per $1 \mathrm{~cm}^{2}$ of the colony.

With the basic information on the morphology and various developmental phases in the life cycle of $S$. rolfsii, the effects of some environmental factors on the above developmental stages were studied.

To study the effect of temperature on sclerotial germination, PDA plates inoculated with mature brown sclerotia harvested from a ten day old colony of $S$. rolfsii were incubated at $10,15,20,25,30,35$ and $40^{\circ} \mathrm{C}$ under continuous illumination for 5 days. The sclerotial germination was determined at $24 \mathrm{~h}$ intervals at the above temperatures. Five plates were used for each temperature.

Similarly, PDA plates were inoculated with $0.8 \mathrm{~cm}$ diameter mycelial discs cut from a 6 day old colony and incubated at the above temperatures for 7 days. The diameters of colonies were measured as before on each day during incubation. Ten plates were used at each temperature to give a total of 20 diameter measurements.

To study the effect of temperature on sclerotial production, PDA plates were inoculated with mycelial discs as described earlier and incubated at room temperature for 3 days. They were then kept at $10,15,20,25,30,35$ and $40^{\circ} \mathrm{C}$ for further 4 days. Sclerotial production was estimated at $24 \mathrm{~h}$ intervals from the third day after initial incubation. Ten plates were used at each temperature.

The effect of $\mathrm{pH}$ was studied only on the germination of sclerotia and the growth of the fungus. $\mathrm{PH}$ of the medium was adjusted to $3.0,4.0,5.0,5.5$, 6.0,7.0,8.0 and 9.0 with a buffer mixture of citric acid/potassium dihydrogen orthophosphate, before being poured into sterile petri dishes. Sclerotia of $S$. rolfsii - Isolate 5 were transferred to PDA plates of different $\mathrm{pHs}$ and were incubated at room temperature for 3 days. The mean percentage germination of sclerotia was determined each day during incubation. Each set up was replicated 5 times. Similarly, mycelial discs were transferred to PDA plates at different $\mathrm{pHs}$ and were incubated for 7 days at room temperature. The diameters of colonies were measured at $24 \mathrm{~h}$ intervals as described earlier.

\section{Results}

Colónies of $S$. rolfsii -- Isolate 5 on PDA were pure white with narrow mycelial strands radiating on the colony surface. The sclerotial initials appeared as tiny white knots of mycelia which later turned pale yellow; pale brown and finally dark brown in colour while they increased in size. Mature brown sclerotia were spherical but slightly flattened below measuring up to 
about $2 \mathrm{~mm}$ across when fresh. The outer wall of sclerotia was shiny and smooth. Primary hyphae of the fungus were $5.0-8.2 \mathrm{~m}$ in breadth and grew along the surface of the medium while the secondary hyphae were usually narrow, about 2-4 $\mathrm{m}$ in breadth and about $350 \mathrm{~m}$ in length and often grew adpressed to the primary hyphae. Tertiary hyphae and other subsequent branches were also narrow and had comparatively short cells. The branching was of tertiary hyphae occurred in a wide angle and was not associated with septation. The tertiary hyphae were usually about $190 \mathrm{~m}$ in length and $1.0-$ $1.8 \mathrm{~m}$ in breadth. Clamp connections were only present on the primary hyphae.

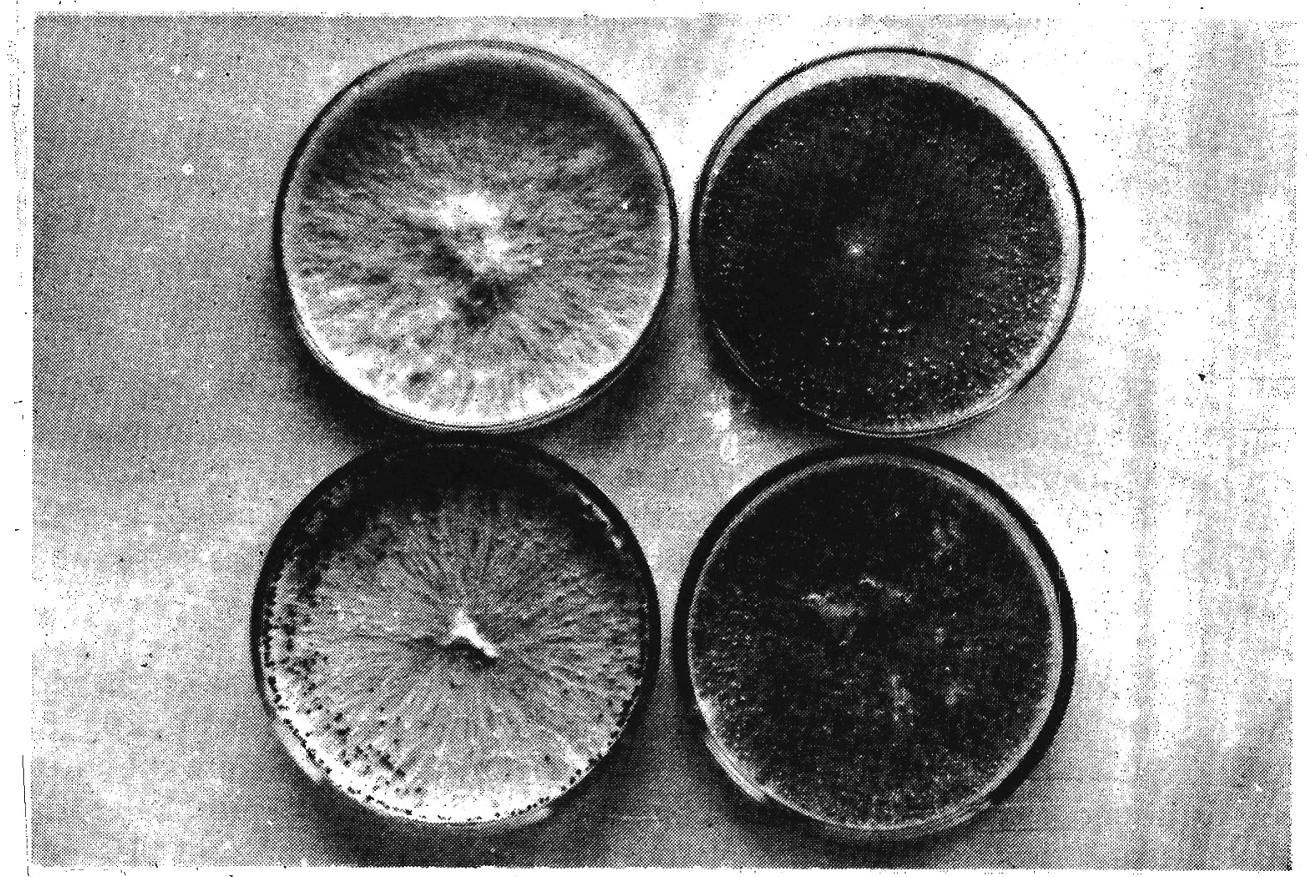

Photograph 1: The mycelium (left top), formation of sclerotial initials (right top), maturation of sclerotia (right bottom) and a mature colony (left bottom) of Sclerotium rolfsii on PDA $\left(\mathrm{X}^{1 / 6}\right)$

Hand sections of the mature sclerotia of $S$. rolfsii - Isolate 5 showed a sharply differentiated outer rind about $1.2-2.0 / \mu \mathrm{m}$ in thickness with strongly pigmented cells. Cortex of the inner region had fairly pigmented small cells and the innermost medulla had large and almost hyaline cells. Reserve materials were found as globules in the cells of cortex and medulla. 


\subsection{Sclerotial germination}

Sclerotia germinated within $24 \mathrm{~h}$ on PDA. The mode of germination was hyphal according to Punja ${ }^{4}$ and the hyphae originated from cells of the medulla in all directions. Mean percentage germination of sclerotia increased significantly at $24 \mathrm{~h}$ intervals during incubation and reached $100 \%$ on the third day after inoculation (Table 1).

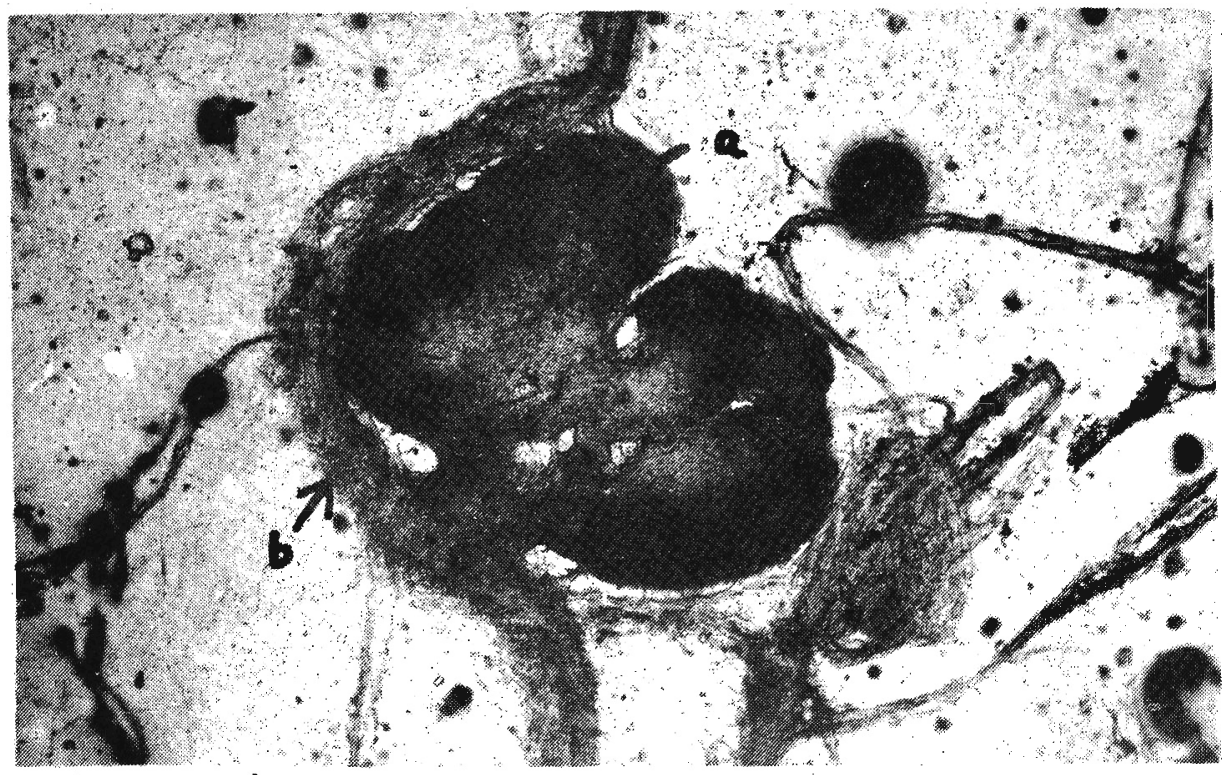

Photograph 2: The T.S. of a developing sclerotial initial (a) and cluster of hyphae (b) taken from a 3 day old colony of $S$. rolfsii on PDA, X40 


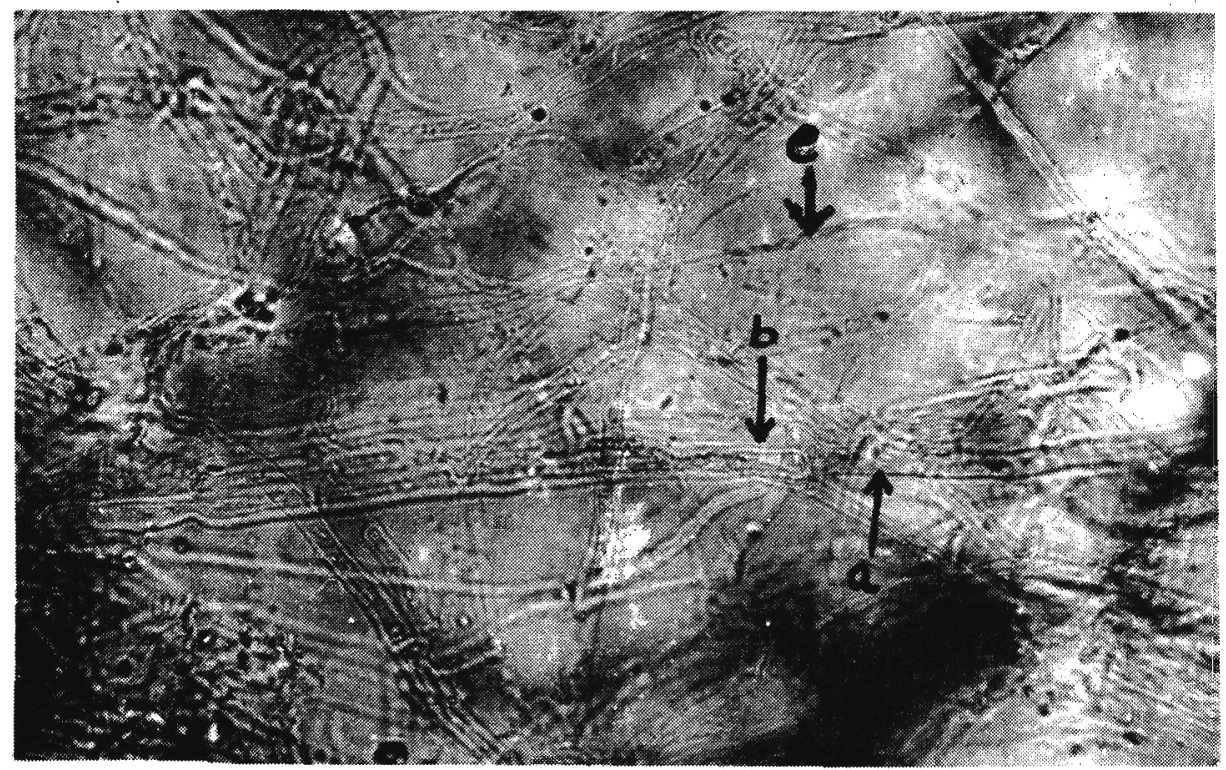

Photograph 3 : Primary (a), secondary (b), and tertiary (c) hyphae taken from a 3 day old colony of $S$. rolfsii on PDA, $\mathrm{X} 400$

Table 1. Sclerotial germination and growth of Sclerotium rolfsii-Isolate 5 after different periods of incubation on PDA.

\begin{tabular}{ccc}
\hline $\begin{array}{c}\text { Period of } \\
\text { incubation } \\
\text { (hours) }\end{array}$ & $\begin{array}{c}\text { Mean \% germination } \\
\text { of sclerotia }\end{array}$ & $\begin{array}{c}\text { Mean diameter of } \\
\text { colony in mm. }\end{array}$ \\
\hline 24 & $40 \mathrm{a}$ & 3.00 \\
48 & $75 \mathrm{~b}$ & 8.50 \\
72 & $100 \mathrm{c}$ & 21.50 \\
96 & 100 & 32.00 \\
120 & 100 & 41.50 \\
\hline
\end{tabular}

Note: Means after different periods of incubation were compared by simple t-test and the values denoted by different letters were found to be statistically different. 
The germinated sclerotia formed tiny white and circular colonies, consisting of sparse hyphae, which become visible after $24 \mathrm{~h}$ of incubation. The colony size increased with the period of incubation (Table 1). The above colonies developed sclerotial initials on the aerial hyphae on the fifth day after inoculation.

Table 2. Effect of temperature on sclerotial germination of Sclerotium rolfsii - Isolate 5 on PDA.

\begin{tabular}{cccccccc}
\hline Period of incubation & \multicolumn{5}{c}{$\begin{array}{c}\text { Mean \% germination of sclerotia } \\
\text { Temperature }\left({ }^{0} \mathrm{C}\right)\end{array}$} \\
\cline { 2 - 7 } (hours) & 10 & 15 & 20 & 25 & 30 & 35 & 40 \\
\hline 24 & 0 & 0 & 0 & 30 & 60 & 65 & 65 \\
48 & 0 & 0 & 0 & 45 & 85 & 100 & 100 \\
72 & 0 & 0 & 0 & 90 & 100 & 100 & 100 \\
96 & 0 & 0 & 0 & 100 & 100 & 100 & 100 \\
120 & 0 & 0 & 0 & 100 & 100 & 100 & 100 \\
\hline
\end{tabular}

\subsection{Radial growth of the fungus}

The fungal mycelium showed luxurious growth on PDA. The colony was pure white and fluffy with dense hyphal strands consisting of $4-5$ individual hyphae per strand. The colonies increased in diameter during incubation and almost covered the entire $9,5 \mathrm{~cm}$ diameter plate in about 5 days (Table 3).

Table 3. Effect of temperature on radial growth of Sclerotium rolfsiiIsolate 5 on PDA.

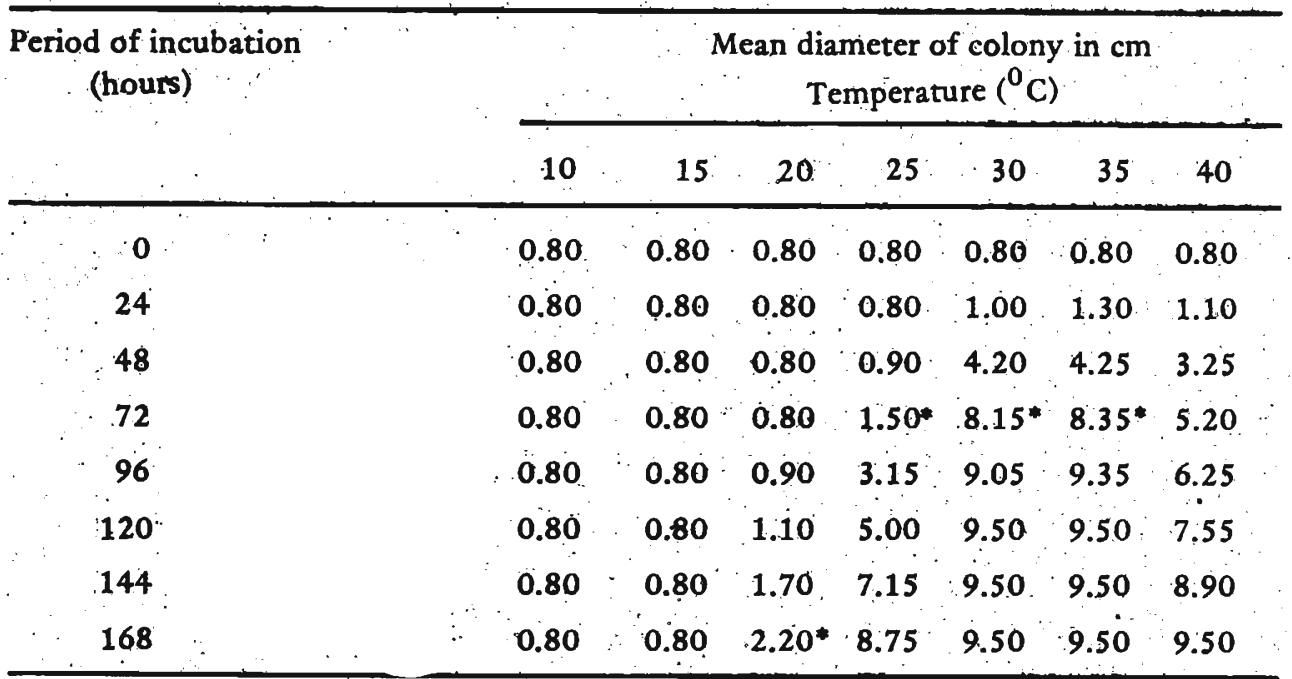

- Formation of sçerotial initials 


\subsection{Production of sclerotia}

Sclerotial initials appeared on the third day after inoculation and turned yellow -brown within two days. The number of immature sclerotia produced increased gradually during the incubation and mature brown sclerotia were seen only on the seventh day after incubation (Table 4).

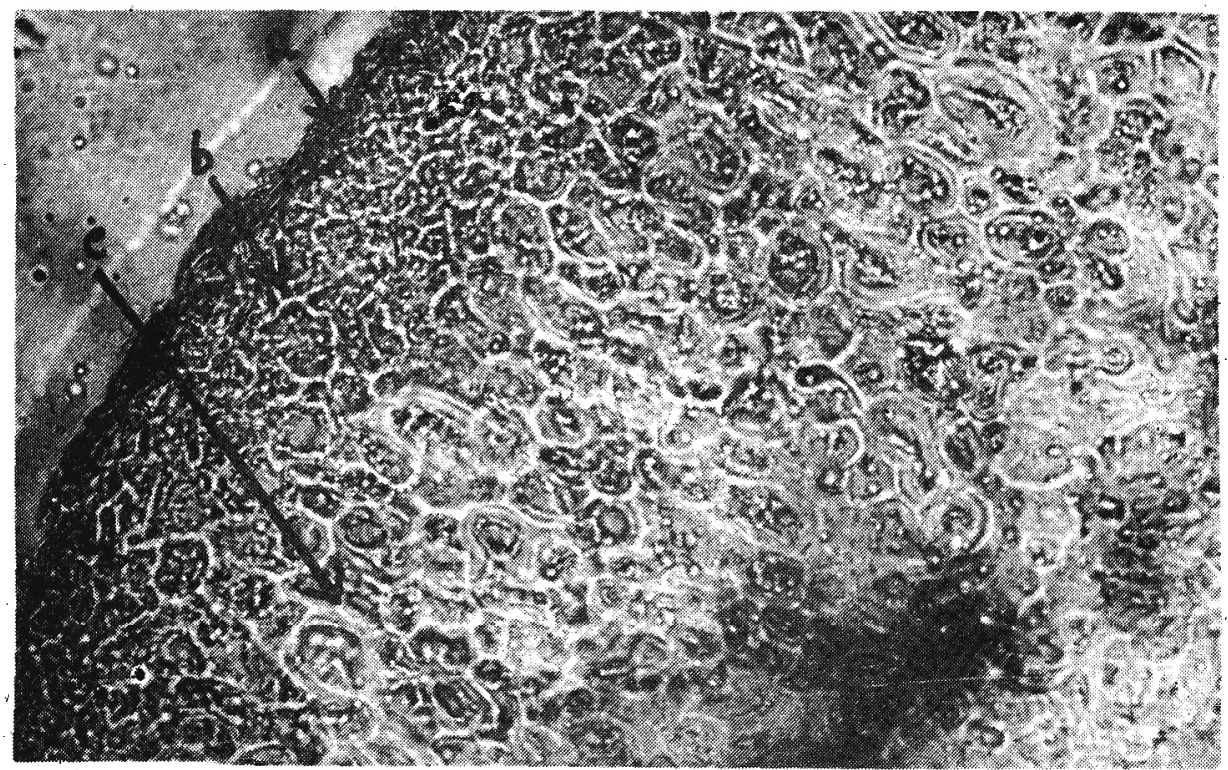

Photograph 4: A portion of T.S. through a mature sclerotium obtained from a 7 day old colony of $S$. rolfsii on PDA. (a) Rind, (b) Cortex, (c) Medullary region X400 
Table 4. Effect of temperature on production of sclerotia of Sclerotium rolfsii - Isolate 5 on PDA.

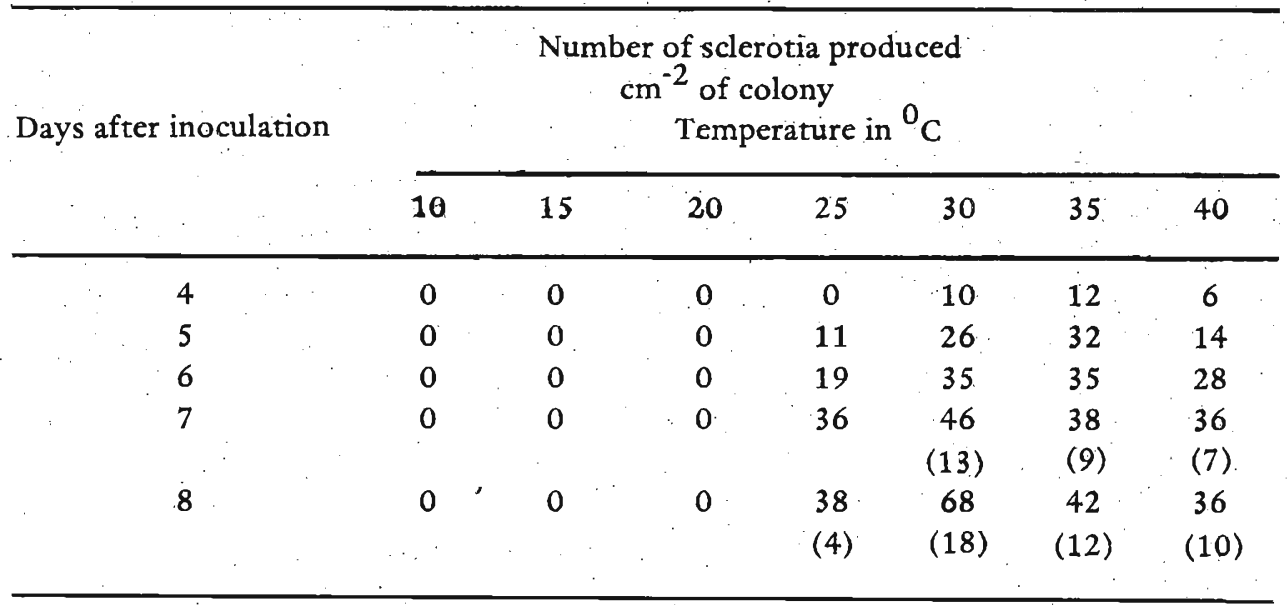

Note: The numbers given within brackets indicate the number of mature brown sclerotia.

\subsection{Effect of temperature on the germination of sclerotia}

Sclerotia failed to germinate at temperatures below. $25^{\circ} \mathrm{C}$ (Table 2). Optimum temperature for germination of sclerotia was around $35^{0} \mathrm{C}$. Mean percentage germination improved with increase in period of incubation.

\subsection{Effect of temperature on the radial growth of the fungus}

Results which appear in Table 3 show that the fungus failed to grow at low temperatures below $15^{\circ} \mathrm{C}$ while the growth was slow at 20 and $25^{\circ} \mathrm{C}$. Best radial growth was observed at temperatures between 30 and $35^{\circ} \mathrm{C}$. White knots of sclerotia appeared in the colony on the third day at 30,35 and $40^{\circ} \mathrm{C}$ and on the sixth day at $25^{\circ} \mathrm{C}$.

\subsection{Effect of temperature on production of sclerotia}

The total number of sclerotia and sclerotial initials formed on the colonies was counted on all the plates at different temperatures after different periods of incubation. From the above data the number of sclerotia and sclerotial initials formed on $1 \mathrm{~cm}^{2}$ of the colony was determined. 
No sclerotia production was observed at temperatures below $25^{\circ} \mathrm{C}$ and maximum amount of sclerotia were produced at temperatures between 30 and $35^{\circ} \mathrm{C}$ (Table 4). The mean number of sclerotial initials produced per $\mathrm{cm}^{2}$ area of colony increased with increase in period of incubation. Mature brown sclerotia were observed on the seventh day after initial inoculation at 30,35 or $40^{\circ} \mathrm{C}$ and on the eighth day at $25^{\circ} \mathrm{C}$.

\subsection{Effect of $\mathrm{pH}$ on sclerotial germination}

Sclerotia germinated at all $\mathrm{pHs}$ tested in this experiment (Table 5). Germination occurred best at $\mathrm{pH}$ 5.5. Germination also improved with increase in period of incubation and was maximum on the third day after inoculation at pHs 4 to 7 .

Table 5. Effect of $\mathrm{pH}$ on sclerotial germination of Sclerotium rolfsii Isolate on PDA.

\begin{tabular}{cccccc} 
& \multicolumn{5}{c}{$\begin{array}{c}\text { Mean \% germination of sclerotia } \\
\text { period of incubation in hours }\end{array}$} \\
\cline { 2 - 6 } $\mathrm{pH}$ & 24 & 48 & 72 & 96 & 120 \\
\hline & & & & & \\
3.0 & 30 & 39 & 62 & & \\
4.0 & 33 & 58 & 100 & 100 & 100 \\
5.0 & 40 & 75 & 100 & 100 & 100 \\
5.5 & 60 & 85 & 100 & 100 & 100 \\
6.0 & 38 & 52 & 100 & 100 & 100 \\
7.0 & 35 & 50 & 100 & 100 & 100 \\
8.0 & 30 & 42 & 78 & 80 & 80 \\
9.0 & 28 & 35 & 58 & 60 & 60 \\
& & & & & \\
\hline
\end{tabular}

\subsection{Effect of $\mathrm{pH}$ on the radial growth of the fungus}

The fungus showed luxurious growth at $\mathrm{pHs}$ between $4-7$ but growth occurred best at pH 5.5 (Table 6 ). The fungus was able to survive a wide range of $\mathrm{pH}$ conditions. 
Table 6. Effect of $\mathrm{pH}$ on radial growth of Sclerotium roifsii - Isolate 5 on PDA.

\begin{tabular}{|c|c|c|c|c|c|c|c|c|}
\hline \multirow{2}{*}{$\mathrm{pH}$} & \multicolumn{6}{|c|}{$\begin{array}{l}\text { Mean diameter of colony in } \mathrm{cm} \text {. } \\
\text { Period of incubation in hours. }\end{array}$} & & \multirow[b]{2}{*}{168} \\
\hline & 0 & 24 & 48 & 72 & 96 & 120 & 144 & \\
\hline 3.0 & 0.80 & 0.82 & 2.86 & 4.22 & 6.96 & 8.15 & 9.06 & 9.50 \\
\hline 4.0 & 0.80 & 0.90 & 3.23 & 7.50 & 8.25 & 9.50 & 9.50 & 9.50 \\
\hline 5.0 & 0.80 & 0.95 & 3.65 & 7.86 & 8.70 & 9.50 & 9.50 & 9.50 \\
\hline 5.5 & 0.80 & 1.00 & 4.20 & 7.94 & 8.95 & 9.50 & 9.50 & 9.50 \\
\hline 6.0 & 0.80 & 0.93 & 4.10 & 7.16 & 8.65 & 9.50 & 9.50 & 9.50 \\
\hline 7.0 & 0.80 & 0.87 & 3.41 & 6.09 & 8.15 & 8.90 & 9.40 & 9.50 \\
\hline 8.0 & 0.80 & 0.80 & 8.00 & 6.00 & 7.45 & 8.30 & 8.78 & 9.20 \\
\hline 9.0 & 0.80 & 0.80 & 2.65 & 5.53 & 6.25 & 6.18 & 7.50 & 8.15 \\
\hline
\end{tabular}

\section{Discussion}

An aerial mycelium composed of both single hyphae and hyphal strands consisting of a few hyphae has been observed on the surface of onion bulbs infected with $S$. rolfsii which has been described as a plant pathogenic soil borne fungus by Aycock. ${ }^{2}$

The active spread of the fungus through the soil following the seasonal rain has been observed in the onion fields in the Arali area of the Jaffna region. The infected bulbs became partially or entirely covered with thick wafts of hyphae which radiate upwards from the base of the stem.

The tiny but macroscopic spherical sclerotia produced in large numbers on and around the rotten bulbs form the outstanding characteristic of the organism. The mature sclerotia obtained from diseased bulbs germinated readily on PDA without any period of dormancy. The fungus took about ten days to produce fresh sclerotia from germinating sclerotia on artificial medium. The observations that sclerotial initials arise from the aerial strands of a colony tally with those made by Townsend and Willetts. ${ }^{6}$

Sclerotia of $S$. rolfsii - Isolate 5 germinated best at $35^{\circ} \mathrm{C}$ while other stages in the fungal development such as radial growth and sclerotial production required an optimum temperature slightly less than $35^{\circ} \mathrm{C}$. This is in accordance with the observation that the soil temperature in the Arali area during the period of disease incidence was around $35^{\circ} \mathrm{C}$.

Although the fungus was found to establish itself in a wide range of $\mathrm{pH}$, 
best performance was obtained at $\mathrm{pH}$ 5.5. The severity of infection in the affected area may be therefore due to the acidic nature of soil $(\mathrm{pH}$ around $6.0)$. Further, studies are underway to control the establishment of the fungus in the field and the spread of the disease.

\section{References}

1. ASSAWAH, M.W., (1977) "Corticium rolfsii (Sacc.) Curzi." In Diseases, pests and weeds in tropical crops. Eds. J. Kranz, H. Schmutterer, W. Kock and Verlog Paul Parey Hambarg.

2. AYCOCK, R., (1966) N.G. Agric. Exp. Stn. Tech. Bull. 174.

3. MORDUE, J.E.M., (1974) "Corticium rolfsii" In descriptions of pathogenic fungi and bacteria. No: 410, Great Britain: CMI.

4. PUNJA, Z.K., (1985) Ann. Rev. Phytopatbol. 23: 97-127.

5. PUNJA, Z.K., HUANG, J.S., \& JENKINS, S.F., (1985) Can. J. Plant Path. 7 : In press.

6. TOWNSEND, B.B. \& WILlETTS, H.J., (1954) Trans. Br. Mycol. Soc. 37 : 213-221.

7. ZOTE, K.K., KHALIKAR, P.V. \& DANDNAIK, S.P., (1982) Madras Agric. J. 70(4):27.5-278. 